Article

\title{
Folic Acid/Methotrexate Functionalized Mesoporous Silica Nanoflakes from Different Supports: Comparative Study
}

\author{
Martyna Trukawka ${ }^{1, *}$, Krzysztof Cendrowski $^{1}$ (D), Wojciech Konicki ${ }^{2}$ and Ewa Mijowska ${ }^{1}$ (D) \\ 1 Department of Nanomaterials Physicochemistry, Faculty of Chemical Technology and Engineering, \\ West Pomeranian University of Technology, Szczecin, Piastów Ave. 42, 71-065 Szczecin, Poland; \\ kcendrowski@zut.edu.pl (K.C.); emijowska@zut.edu.pl (E.M.) \\ 2 Department of Integrated Transport Technology and Environmental Protection, Maritime University of \\ Szczecin, H. Pobożnego St. 11, 70-507 Szczecin, Poland; w.konicki@am.szczecin.pl \\ * Correspondence: martyna.barylak@zut.edu.pl
}

Received: 24 August 2020; Accepted: 10 September 2020; Published: 17 September 2020

\begin{abstract}
Herein, we present a facile synthesis route for the mesoporous silica nanoflakes on two types of templates and evaluate their potential as potential drug delivery systems. Silica materials are attractive due to their biocompatibility, low cytotoxicity, high surface area, and tunable pores. In addition, they can be multifunctionalized. These properties were used to create multifunctional drug delivery systems combining folic acid as a target molecule and methotrexate (MTX) as an anticancer drug. The silica nanoflakes were formed using graphene oxide and double-layered hydroxide as templates, respectively. After the removal of matrices, the silica flakes were functionalized by folic acid and loaded with methotrexate. The differences in drug release performance and structural stability were analyzed with respect to the detailed physicochemical characterization of the produced silica nanoflakes.
\end{abstract}

Keywords: silica flakes; anticancer drugs; targeted therapy; drug carrier; multifunctional drugs; folic acid/methotrexate

\section{Introduction}

In recent years, 2D materials have become more and more popular. This was started in 2004 when Novoselov, Geim, and co-workers successfully received graphene by exfoliating graphite with Scotch tape. Layered materials, due to their unique physicochemical properties, can be used in many areas such as chemistry, electronics, and material engineering [1]. In addition, the large surface area of 2D materials makes them suitable for catalysis [2] or sensing. There are also records reporting derivative 2D materials including mesoporous silica on graphene, graphene oxide, or reduced graphene oxide. Yang and co-workers have described the synthesis of mesoporous silica on graphene using cetyl trimethyl ammonium bromide (CTAB) as a structure-directing agent. They believe that this material can be potentially used for lithium ion storage [3]. Wang et al. have successfully synthesized a composite of mesoporous silica with aligned channels vertically to the surface of single-layer graphene oxide. This material shows interesting semi-conductive behavior and sensing property [4]. Guardia and his co-workers have reported the synthesis and characterization of small-size mesoporous silica nanoparticles on graphene and explored the effect of experimental parameters such as $\mathrm{pH}$ value and the amount of raw materials on the properties and morphology [5]. Liu et al. have described the synthesis of sandwich-like nanosheets from reduced graphene oxide and mesoporous silica with size tunable vertical mesochannels by an oil-water biphase stratification. They assume that the resultant 
nanosheets would have a prospect in a large-molecule-weight drug delivery system, which would have both chemical and photothermal therapeutic functions [6].

There is also a report on the formation of a mesoporous silica shell on the surface of double-layered magnesium and aluminum hydroxide (LDH). This research has demonstrated precise control of the thickness and the pore diameter of the $\mathrm{mSiO}_{2}$ shell on the $\mathrm{LDH} \mathrm{Mg} / \mathrm{Al}$ surface by adjusting the relative amount of $\mathrm{LDH} \mathrm{Mg} / \mathrm{Al}$ or tetraethyl orthosilicate (TEOS) and using the soft template with various hydrocarbon chain lengths [7].

Mesoporous silica and other forms of silica are attractive because of their unique properties such as a hydrophilic surface that is suitable to adsorb some functional groups, tunable size (60 nm-10 $\mu \mathrm{m})$ [8], ease of surface functionalization, and low cost of nanoparticles production $[9,10]$. However, one of the most important features of silica, thanks to which it can be used in biomedical applications, is its biocompatibility [11] and high specific surface area [12]. Both pristine and functionalized silica spheres have been widely studied for bioapplications-among others, for the storage and release of drugs [13,14], biosensing [15] and tracking cells [16], hyperthermia [17], and phototherapy [18]. There are also reports regarding functionalization of the silica surface with specific functional groups for targeting purposes. Antibodies [19], aptamers [20], and folic acid [21] have been used for this assignment. Most of the reports are about solid or mesoporous spheres. The flake-like structure of the silica is not yet well studied in this regard. According to the literature, it is possible to produce the nano- and mesoporous silica flakes. Shan et al. have successfully synthesized lotus-leaf-like nanoporous silica flakes using 1-hexadecylamine and tetraethylorthosilicate. They determined that the thickness of the flakes is dependent on the concentration of TEOS. Their structure showed better adsorption properties than its microspheric analogues. The authors also supposed that flake-like properties may allow using them as a support for catalysts [22]. Xiao and co-workers have reported the preparation of silica nanoflakes using dual-template synthesis. The pore architectures and morphologies were controlled by the F127 block copolymer and the self-assemblies chiral low-molecular-weight amphiphiles, respectively [23].

Our previous studies concerning the flake-like structures yielded very promising results. The synthesis and characterization of mesoporous silica flakes obtained on a graphene oxide template for use as a carrier of anticancer drug was presented. The mesoporous silica flakes were able to pack significant amounts of the drug, and its release was long-term [24]. In addition, both the pristine flakes and the complex with the drug have been tested for biocompatibility and cytotoxicity. Their biodistribution in internal organs has been also evaluated. The cytotoxicity of the nanoflakes-methotrexate (MTX) complex in reference to MTX showed similar cytotoxic potential against cancer cells. These data have provided useful information for designing drug delivery systems, which may improve anticancer efficacy and decrease side effects [25]. The obtained results inspired the authors to create a multifunctional structure. Functionalization with targeting molecules allows fully exploiting the potential of mesoporous silica flakes in anticancer drug delivery. In this contribution, we present the synthesis and characterization of mesoporous silica flakes obtained on two different templates: graphene oxide and double-layer magnesium and aluminum hydroxide. These matrixes were removed before functionalization with folic acid and anticancer drug loading. Folic acid was used as the targeting molecule, because some of the cancer cells have over-expressed folate receptors on their surfaces and are able to attract nanostructures functionalized with folic acid [26]. Methotrexate as a model anticancer drug was used. It is one of the earliest anticancer drugs and is extensively used in lymphoma, acute lymphoblastic leukemia, and osteosarcoma, among others. By inhibiting metabolic pathways, it prevents the synthesis of purine bases, which are necessary elements in the structure of DNA. The consequence is a disorder in the synthesis of DNA as well as RNA and proteins, which leads to the inhibition of cell division and to apoptotic cell death [27]. In this work, the physicochemical properties of mesoporous silica flakes produced on two types of matrices functionalized with folic acid were checked and compared. The effect of this functionalization on the ability to load and release the drug has also been tested. 


\section{Materials and Methods}

\subsection{Materials}

Graphite was purchased from Alfa Aesar (synthetic, 99.9995\%, 325 mesh). Orthophosphoric acid, sulfuric acid, hydrochloric acid, ammonia, and ethanol were obtained from Chempur (Piekary Slaskie, Poland). Magnesium nitrate hexahydrate, hexadecyltrimethylammonium bromide (CTAB), tetraethyl orthosilicate (TEOS), (3-aminopropyl)triethoxysilane (APTES), folic acid, and methotrexate (MTX) were bought from MERCK (MERCK, Darmstadt, Germany). Potassium permanganate and aluminum hydroxide were purchased from Avantor Performance Materials Poland S.A. (Gliwice, Poland).

\subsection{Synthesis of Mesoporous Silica Flakes}

Graphene oxide was prepared by the oxidation of natural graphite flakes according to the modified Hummers method. Briefly, a mixture of orthophosphoric acid and sulfuric acid (15:120 mL) was added to $\mathrm{KMnO}_{4}(6 \mathrm{~g})$ and graphite $(1 \mathrm{~g})$. It was heated while stirring to $50{ }^{\circ} \mathrm{C}$ for $20 \mathrm{~h}$. After cooling down, $150 \mathrm{~mL}$ of ice and $1 \mathrm{~mL}$ of $\mathrm{H}_{2} \mathrm{O}_{2}$ was added to the resulting product. The obtained material was centrifuged and washed with water, $30 \% \mathrm{HCl}$, and ethanol twice before vacuum drying.

Next, $100 \mathrm{~g}$ of graphene oxide (GO) was dispersed in a mixture of water $(100 \mathrm{~mL})$, ethanol $(120 \mathrm{~mL})$, and CTAB $(240 \mathrm{mg})$. Afterwards, ammonia $(0.225 \mathrm{~mL})$ was added. The suspension was sonicated until stable dispersion was obtained. Then, $0.375 \mathrm{~mL}$ TEOS was added and stirred for $24 \mathrm{~h}$. The product was dried at $80{ }^{\circ} \mathrm{C}$ for $10 \mathrm{~h}$ and placed in an oven at $700{ }^{\circ} \mathrm{C}$ to remove $\mathrm{CTAB}$ and graphene oxide sheets. The material was designated as $\mathrm{mSiO}_{2}$ after GO.

To obtain $\mathrm{LDH} \mathrm{Mg} / \mathrm{Al}$, at first, $\mathrm{Mg}\left(\mathrm{NO}_{3}\right)_{2} \cdot 6 \mathrm{H}_{2} \mathrm{O}$ and $\mathrm{Al}(\mathrm{OH})_{3}$ was calcinated for $4 \mathrm{~h}$ in an oven at $600{ }^{\circ} \mathrm{C}$. Then, $\mathrm{Al}_{2} \mathrm{O}_{3}(102 \mathrm{mg})$ and $\mathrm{MgO}(162 \mathrm{mg})$ were dispersed in water $(40 \mathrm{~mL})$. The stable suspension was placed in an autoclave at $110^{\circ} \mathrm{C}$ for 5 days. The product was centrifuged, washed with water twice, and dried at $80^{\circ} \mathrm{C}$ for $10 \mathrm{~h}$. The procedure of mesoporous silica on the surface of LDH $\mathrm{Mg} / \mathrm{Al}$ formation was the same as for graphene oxide. However, the step to remove the matrix from $\mathrm{LDH} \mathrm{Mg/Al} \mathrm{has} \mathrm{been} \mathrm{added.} \mathrm{The} \mathrm{product} \mathrm{after} \mathrm{the} \mathrm{removal} \mathrm{of} \mathrm{CTAB} \mathrm{was} \mathrm{placed} \mathrm{in} \mathrm{HCl}$ for $48 \mathrm{~h}$. After this time, the material was filtered, washed with water, and dried at $80^{\circ} \mathrm{C}$. The sample was designated as $\mathrm{mSiO}_{2}$ after $\mathrm{LDH} \mathrm{Mg} / \mathrm{Al}$.

\subsection{Folic Acid Functionalization}

Both samples ( $\mathrm{mSiO}_{2}$ after $\mathrm{GO}$ and $\mathrm{mSiO}_{2}$ after $\left.\mathrm{LDH} \mathrm{Mg} / \mathrm{Al}\right)$ were functionalized following the same method. At first, $100 \mathrm{mg}$ of flakes were dispersed in $100 \mathrm{~mL}$ of toluene and placed under reflux. After reaching the set temperature, $5 \mu \mathrm{L}$ APTES was added to the mixture and the reaction was carried out for $1 \mathrm{~h}$. After this time, the samples were centrifuged and dried at $40^{\circ} \mathrm{C}$.

Then, $10 \mathrm{mg}$ of folic acid was dispersed in $200 \mathrm{~mL}$ of isopropanol with $50 \mathrm{mg}$ of $\mathrm{EDC} \cdot \mathrm{HCl}$ and $30 \mathrm{mg}$ of NHS. After $3 \mathrm{~h}, 50 \mathrm{mg}$ of $\mathrm{mSiO}_{2}$ after $\mathrm{GO}$ or $\mathrm{mSiO}_{2}$ after $\mathrm{LDH} \mathrm{Mg} / \mathrm{Al}$ was added to the mixture and stirred overnight. The product was centrifuged and vacuum dried.

\subsection{Drug Loading}

MTX was dissolved in water $(0.5 \mathrm{mg} / \mathrm{mL})$. After drug dissolving, silica flakes were added at a ratio of 1:2 (MTX: $\mathrm{mSiO}_{2}$ FA). The mixture was stirred for $20 \mathrm{~h}$ and then centrifuged, washed with water, and dried at $37^{\circ} \mathrm{C}$

\subsection{Release Study}

The release study of $\mathrm{MTX}$ from $\mathrm{mSiO}_{2}$ after $\mathrm{GO}_{-} \mathrm{FA} \_\mathrm{MTX}$ and $\mathrm{mSiO}_{2}$ after $\mathrm{LDH} \mathrm{Mg} / \mathrm{Al}$ _FA_MTX was performed using the bath technique at $37^{\circ} \mathrm{C}$. About $2.8 \mathrm{mg}$ of the nanomaterials were added into the flasks containing $100 \mathrm{~mL}$ of deionized water or phosphate-buffered saline (PBS) (MERCK, Darmstadt, Germany). The flasks with solutions were placed in a constant temperature bath and agitated with a 
magnetic stirrer in order to achieve homogeneity. When the desired temperature was reached, the $\mathrm{mSiO}_{2}$ FA_MTX was added into the flask. At set intervals, $1 \mathrm{~mL}$ was taken from the solution to separate the solution and solid phase (centrifugation at $6000 \mathrm{rpm}$ for $3 \mathrm{~min}$ ). The concentrations of MTX after desorption in the supernatant solution were determined spectrophotometrically using a UV-vis spectrophotometer GENESYS $10 S$ (Thermo Fisher Scientific, Waltham, MA, USA) at an $\lambda$ max value of $307 \mathrm{~nm}$. Each experiment was performed three times, and the results are given as average values.

\subsection{Degradation of Silica Flakes}

The experiment of silica flakes degradation was carried out by placing $3 \mathrm{mg}$ of silica flakes in $3 \mathrm{~mL}$ of deionized water, phosphate buffer saline, or Dulbecco's Modified Eagles Medium (MERCK, Darmstadt, Germany). At designated intervals (24, 48, and $72 \mathrm{~h}$ ) each material was collected by centrifuging and washed with water and ethanol to get rid of the remaining solvent.

\subsection{Characterization Techniques}

The composition of the samples and their structure was analyzed by transmission electron microscopy (TEM; Tecnai F30, Thermo Fisher Scientific, Waltham, MA, USA) using an FEI Tecnai G2 F20 S Twin with an accelerating voltage of $200 \mathrm{kV}$, and X-ray dispersion spectroscopy (EDX, EDS, EDAX, Mahwah, NJ, USA). The morphology of the samples was investigated by scanning electron microscopy (SEM; VEGA3 TESCAN, Brno, Czech Republic), which was acquired in the $30 \mathrm{kV}$ acceleration voltage. In order to study the thickness of obtained silica flakes, atomic force microscopy (AFM) (Nanoscope V Multimode 8, Bruker AXS, Mannheim, Germany) was employed. The analysis of the sample composition was made using an Invia Renishaw Raman spectroscope, with a spectral range from 2100 to $100 \mathrm{~cm}^{-1}$, using a laser with a length of $785 \mathrm{~nm}$ (Renishaw, New Mills Wotton-under-Edge, UK). Thermogravimetric analysis (TGA; TA Instrument, New Castle, DE, USA) was carried out on $10 \mathrm{mg}$ samples using a DTA-Q600 SDT TA at a heating rate of $10^{\circ} \mathrm{C} / \mathrm{min}$ from room temperature to $900^{\circ} \mathrm{C}$ in air. The crystallographic phase identification was performed using an X'Pert Philips PROX-ray diffractometer (XRD; X'Pert PRO Philips diffractometer, Co. Ka radiation, Almelo, Holland). The specific surface area of the samples was measured through the adsorption of the $\mathrm{N}_{2}$ isotherm using the Micromeritics ASAP ${ }^{\circledR} 2420$ (Micromeritics ASAP ${ }^{\circledR}$, USA) instrument, interpreted with the Brunauer-Emmett-Teller model. IR absorption spectra were acquired on the Nicolet 6700 FT-IR spectrometer (Thermo Fisher Scientific, Waltham, MA, USA).

\section{Results}

\subsection{Silica Nanoflakes Characterization}

The morphology of the obtained materials was studied with transmission electron microscopy and scanning electron microscopy. Figure $1 \mathrm{~A}$ presents graphene oxide and Figure $1 \mathrm{~B}, \mathrm{C}$ reveals the morphology of obtained silica flakes after $\mathrm{GO}$ removal. $\mathrm{LDH} \mathrm{Mg} / \mathrm{Al}$ and the formed silica flakes on them are presented in Figure 1D-F, respectively. The porous structure of silica flakes obtained on both templates is clearly visible. In the flakes obtained on $\mathrm{LDH} \mathrm{Mg} / \mathrm{Al}$, a mesoporous shell was also deposited on the edges (see Figure 1F). In the case of flakes obtained on graphene oxide, it can be assumed that the deposition took place only on the planes of graphene oxide. 

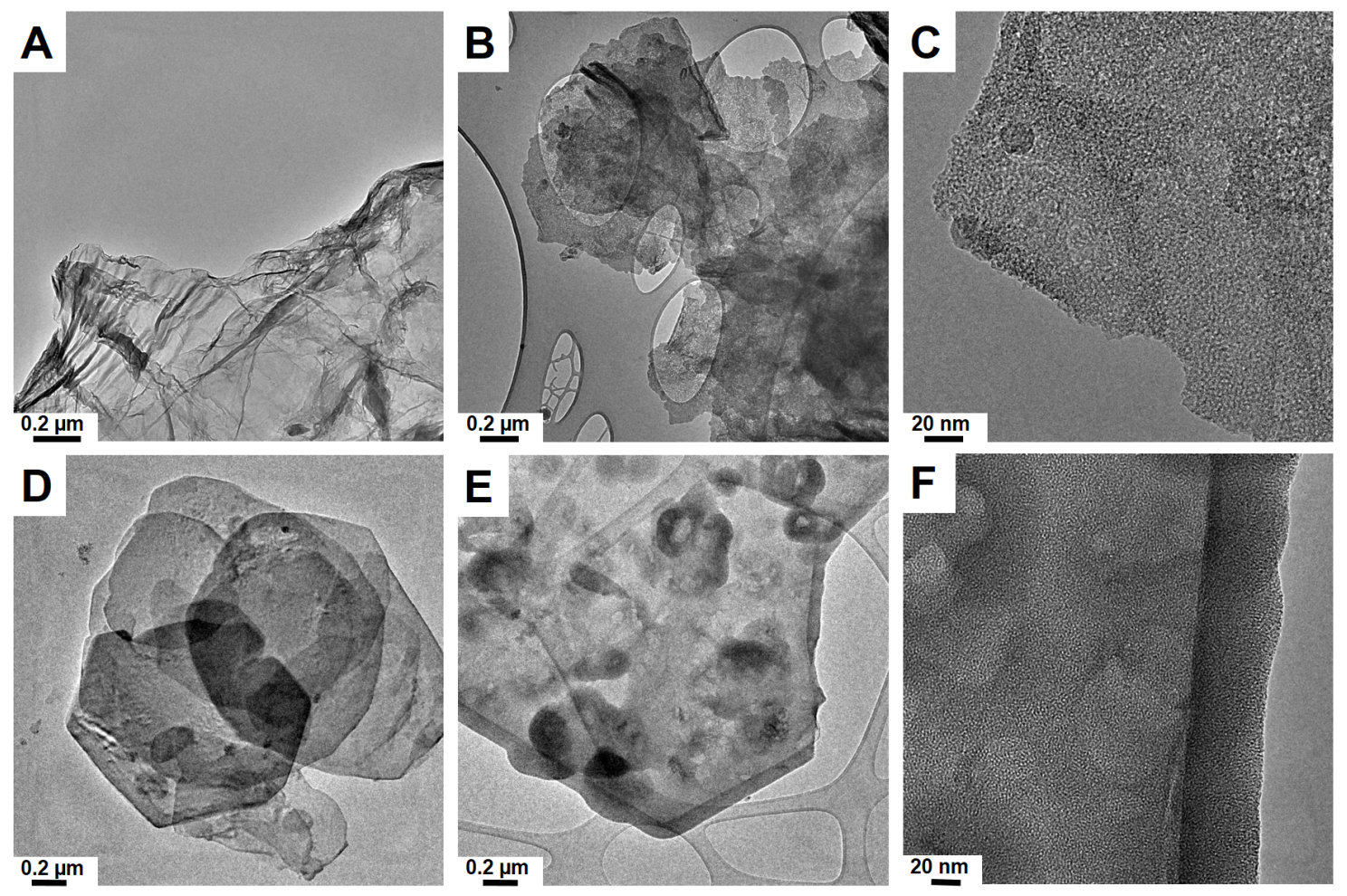

Figure 1. Transmission electron microscopy image of graphene oxide (GO) (A) and silica flakes obtained on GO (B,C); double-layered magnesium and aluminum hydroxide LDH (D) and obtained on LDH $\mathrm{Mg} / \mathrm{Al}(\mathbf{E}, \mathbf{F})$.

Elemental analysis of silica flakes and templates were carried out using X-ray dispersion spectroscopy as the TEM mode. Supplementary Materials Figure S1 shows an EDX analysis of templates and silica flakes after removal of the templates. Elemental analysis of graphene oxide confirmed that the sample consists of carbon and oxygen. In an EDX spectrum of LDH Mg/Al, there are signals from oxygen, aluminum, and magnesium. For both samples, the analysis showed that they consist of oxygen and silicon elements. The analysis confirms that the templates were effectively removed from the silica flakes. All the samples have copper signals that originate from the TEM grids.

The thickness and size distribution of the nanostructures were estimated using atomic force microscopy. Basing on analysis of the AFM images (Figure 2), it was determined that the size of the flakes formed on the graphene oxide template is in the range of $40-220 \mathrm{~nm}$, with the peak in the range of $80-100 \mathrm{~nm}$. The flakes fabricated on the $\mathrm{LDH} \mathrm{Mg} / \mathrm{Al}$ were in the range of $200-1000 \mathrm{~nm}$ with the peak in the range of 400-500 nm. The obtained materials differed in thickness as well. The flakes obtained on the $\mathrm{LDH} \mathrm{Mg} / \mathrm{Al}$ template were larger and thicker than those obtained on graphene oxide. Flakes of $\mathrm{mSiO}_{2}$ after GO thickness were $\approx 4 \mathrm{~nm}$, while those of $\mathrm{mSiO}_{2}$ after $\mathrm{LDH} \mathrm{Mg} / \mathrm{Al}$ were $\approx 6.5 \mathrm{~nm}$. 

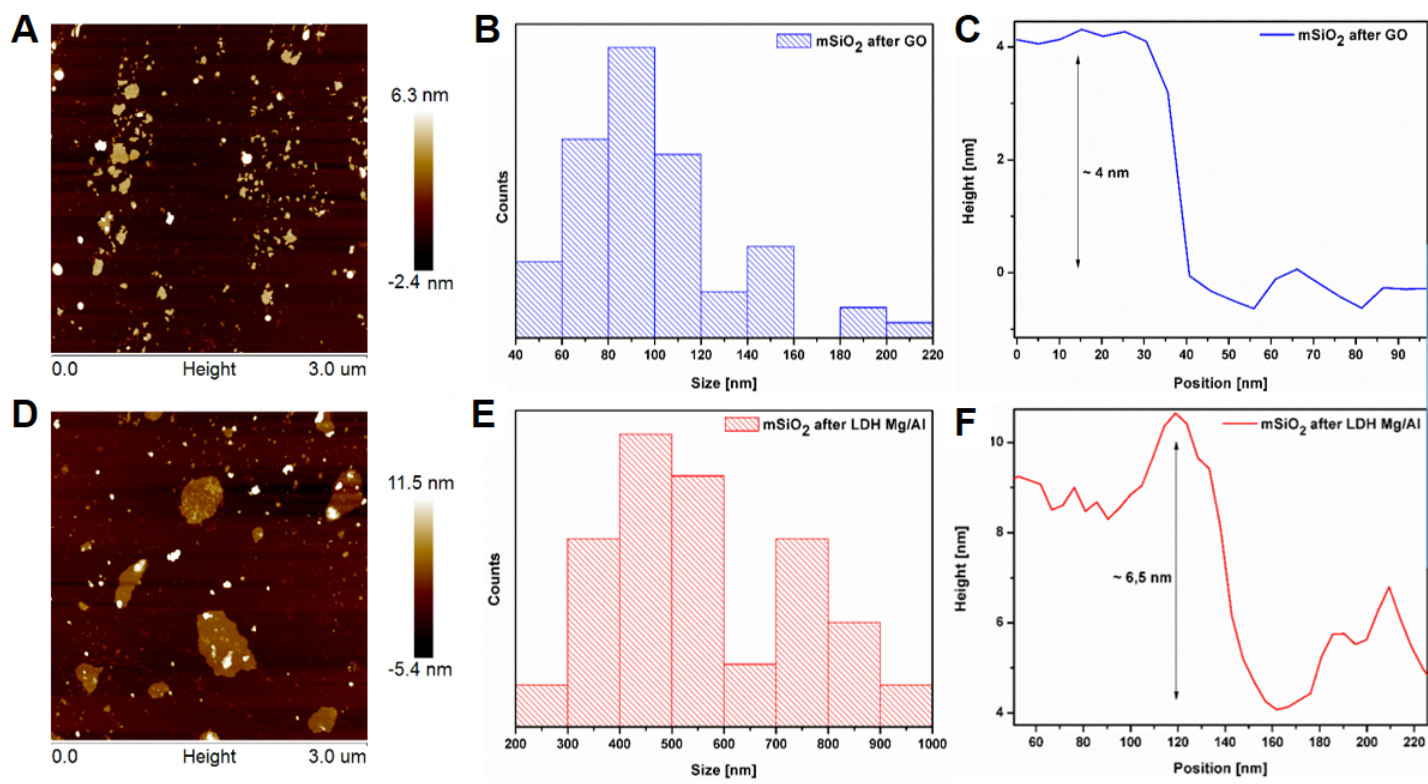

Figure 2. Atomic force microscopic images (A,D), flakes size distributions (B,E), and height profiles $(\mathbf{C}, \mathbf{F})$ of selected $\mathrm{mSiO}_{2}$ after $\mathrm{GO}$ (upper panel) and $\mathrm{mSiO}_{2}$ after $\mathrm{LDH} \mathrm{Mg} / \mathrm{Al}$ (lower panel).

Figure $\mathrm{S} 2$ presents $\mathrm{XRD}$ patterns of $\mathrm{GO}, \mathrm{mSiO}_{2}$ after $\mathrm{GO}, \mathrm{LDH} \mathrm{Mg} / \mathrm{Al}$, and $\mathrm{mSiO}_{2}$ after $\mathrm{LDH} \mathrm{Mg} / \mathrm{Al}$. The GO and $\mathrm{LDH} \mathrm{Mg/Al} \mathrm{pattern} \mathrm{exhibits} \mathrm{strong,} \mathrm{characteristic} \mathrm{peaks} \mathrm{corresponding} \mathrm{to} \mathrm{the} \mathrm{(002)} \mathrm{plane}$ of GO and (003), (006), and (009) planes of LDH [28]. After purification, silica flakes show the broad peak at $22^{\circ}$ indicating that the flakes are composed only from amorphous silica. The detailed pattern analysis and XRD patterns are presented in the supporting information. Raman analysis presented in the supporting information (images A and B in Figure S3) proved that the pristine template was GO and $\mathrm{LDH} \mathrm{Mg} / \mathrm{Al}$, and after purification, obtained flakes are composed of silica.

The surface area, pore volume, and diameter distribution of the mesoporous silica flakes $\left(\mathrm{mSiO}_{2}\right)$ from both templates (Table 1) were calculated using the Brunauer, Emmett, and Teller (BET) method (isotherms and pore diameter distribution are presented in the supporting information). Figure S4A presents $\mathrm{N}_{2}$ adsorption/desorption isotherms and the pore size distribution of both samples. From the multipoint BET isotherm, total surface areas were calculated to be $738 \mathrm{~m}^{2} / \mathrm{g}$ and $839 \mathrm{~m}^{2} / \mathrm{g}$ for $\mathrm{mSiO}_{2}$ after $\mathrm{GO}$ and $\mathrm{mSiO}_{2}$ after $\mathrm{LDH} \mathrm{Mg/Al}$, respectively. The isotherms, identified as type IV according to the International Union of Pure and Applied Chemistry (IUPAC) classification, are typical for mesoporous materials [29]. The volume of pores reached the value of $0.1501 \mathrm{~cm}^{3} / \mathrm{g}$ (according the Barrett, Joyner and Halenda method-BJH method), while their diameters (Figure S4B) were estimated in the range between 1.95 and $6 \mathrm{~nm}$, with the peak in the range from 1.95 to $3 \mathrm{~nm}$, for $\mathrm{mSiO}_{2}$ after GO. For the flakes after removal of LDH Mg/Al, the pore volume was calculated to be $0.052 \mathrm{~cm}^{3} / \mathrm{g}$ (followed by the BJH method), and their diameters were in the range of 2.2 and $4.85 \mathrm{~nm}$ (Figure S4B). The contribution of pores with a larger diameter causes the specific surface area of the flakes after GO to be lower. In addition, the thickness and size of flakes for porous structures is crucial. The specific surface area is closely related to these dimensions, and despite the smaller diameter and pore volume, the overall surface area would be higher if the flakes are larger and thicker. The synthesis procedure of mesoporous silica, as well as pore volume and diameter distributions, is consistent with literature data, where CTAB was used as surfactant for synthesis MCM-41 type nanostructures [30,31]. 
Table 1. Brunauer, Emmett, and Teller (BET) surface area, pore size, and volume of silica flakes.

\begin{tabular}{|c|c|c|c|c|c|}
\hline Sample & $\begin{array}{l}\text { SBET } \\
\left(\mathrm{m}^{2} / \mathrm{g}\right)\end{array}$ & $\begin{array}{l}\text { VTOTAL } \\
\left(\mathrm{cm}^{3} / \mathrm{g}\right)\end{array}$ & $\begin{array}{l}\text { Pore Size } \\
\text { (nm) }\end{array}$ & $\begin{array}{c}\text { Flake Size } \\
\text { (nm) }\end{array}$ & $\begin{array}{c}\text { Flake } \\
\text { Thickness }\end{array}$ \\
\hline $\mathrm{mSiO}_{2}$ after $\mathrm{GO}$ & 738 & 0.1501 & $\begin{array}{c}1.95-6 \\
(1.95-3)\end{array}$ & $\begin{array}{c}40-220 \\
(80-100)\end{array}$ & $\sim 4$ \\
\hline $\begin{array}{l}\mathrm{mSiO}_{2} \text { after } \\
\mathrm{LDH} \mathrm{Mg} / \mathrm{Al}\end{array}$ & 839 & 0.052 & $\begin{array}{l}2.2-4.85 \\
(2.2-3.4)\end{array}$ & $\begin{array}{l}200-1000 \\
(400-500)\end{array}$ & $\sim 6.5$ \\
\hline
\end{tabular}

To confirm the functionalization of silica flakes with folic acid, spectra from Fourier-transform infrared spectroscopy (FTIR) were recorded (Figure 3). The spectra of all samples show bands characteristic for silica. The band at $460 \mathrm{~cm}^{-1}$ and $585 \mathrm{~cm}^{-1}$ corresponded to the out of plane of Si-O bonds. The strong peaks that appeared at around 1089,960, and $812 \mathrm{~cm}^{-1}$ are due to the stretching vibration of $\mathrm{Si}-\mathrm{O}-\mathrm{Si}, \mathrm{Si}-\mathrm{OH}$, and $\mathrm{Si}-\mathrm{O}$, which are specific peaks of the silica nanoparticles, and the broad band around $3400 \mathrm{~cm}^{-1}$ can be attributed to the $\mathrm{O}-\mathrm{H}$ groups [32]. The band around 1640 $\mathrm{cm}^{-1}$ belongs to adsorbed water. In both samples after functionalization, characteristic peaks for folic acid appeared. The peak at $\approx 665 \mathrm{~cm}^{-1}$ or $\approx 730 \mathrm{~cm}^{-1}$ can be attributed to amine bonds $\left(\mathrm{NH}_{2}\right)$ [33]. The presence of a weak band around $2880-2920 \mathrm{~cm}^{-1}$ is attributed to $(\mathrm{C}-\mathrm{H})$ of $\mathrm{CH}_{2}$ groups of FA. The band at $\approx 1510 \mathrm{~cm}^{-1}$ belongs to the aromatic rings vibration $(C=C)$ of FA. The intensity of the peak at $1704 \mathrm{~cm}^{-1}$ increased, which is probably due to the formation of amide bonds between the FA and nanoflakes [34].
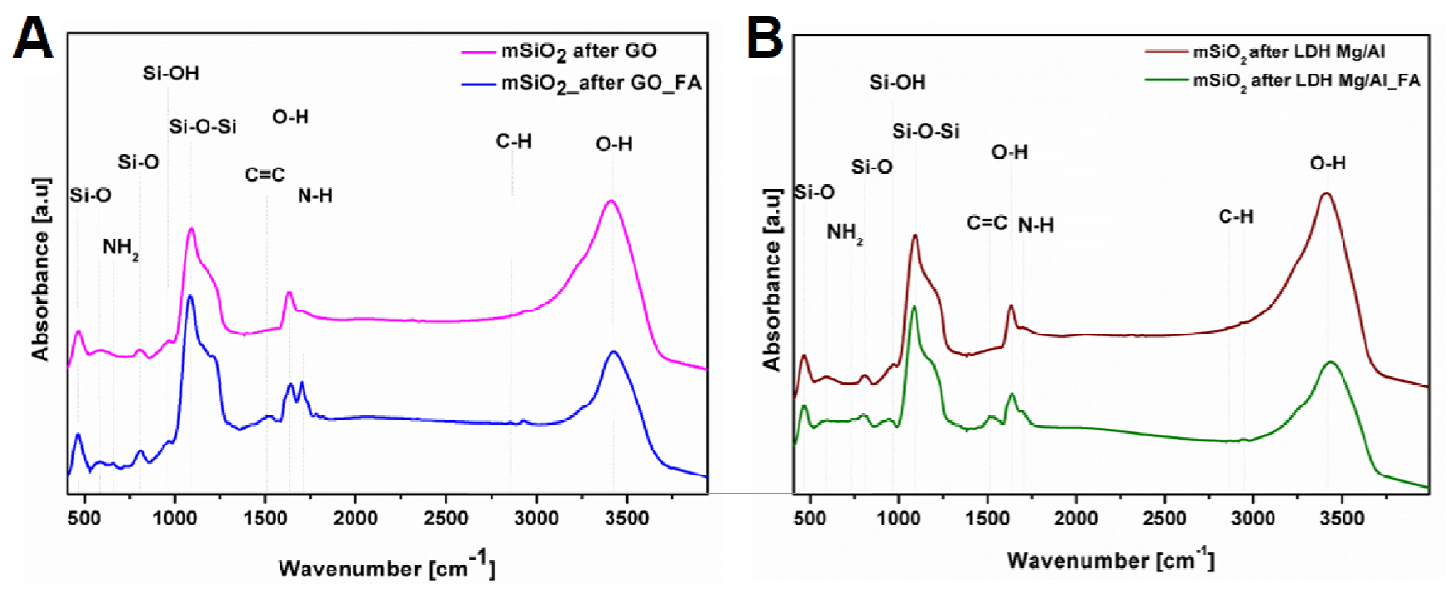

Figure 3. FTIR spectra of silica flakes functionalized with folic acid: $\mathrm{mSiO}_{2}$ after $\mathrm{GO}_{-} \mathrm{FA}(\mathrm{A})$ and $\mathrm{mSiO}_{2}$ after LDH Mg/Al_FA (B).

Most of the vibrational bands from folic acid in Raman spectrum (Figure 4) are in the range from 600 to $1700 \mathrm{~cm}^{-1}$. The peak at $\approx 1610 \mathrm{~cm}^{-1}$ can be related to the stretching vibration of $\mathrm{N}-\mathrm{H}$. The band $\approx 1570 \mathrm{~cm}^{-1}$ derives from $\mathrm{C}=\mathrm{N}$. The bands at $1359 \mathrm{~cm}^{-1}$ and $1302 \mathrm{can}$ be described as a rocking vibration of $\mathrm{CH}$. The peaks at $1198 \mathrm{~cm}^{-1}$ and $682 \mathrm{~cm}^{-1}$ can be related to $\mathrm{C}=\mathrm{C}$ [35-37]. These most characteristic bands of folic acid are detected in the samples after folic acid functionalization, confirming the effective attachment of folic acid to the silica flakes formed both on $\mathrm{LDH} \mathrm{Mg/Al}$ and on GO templates. 

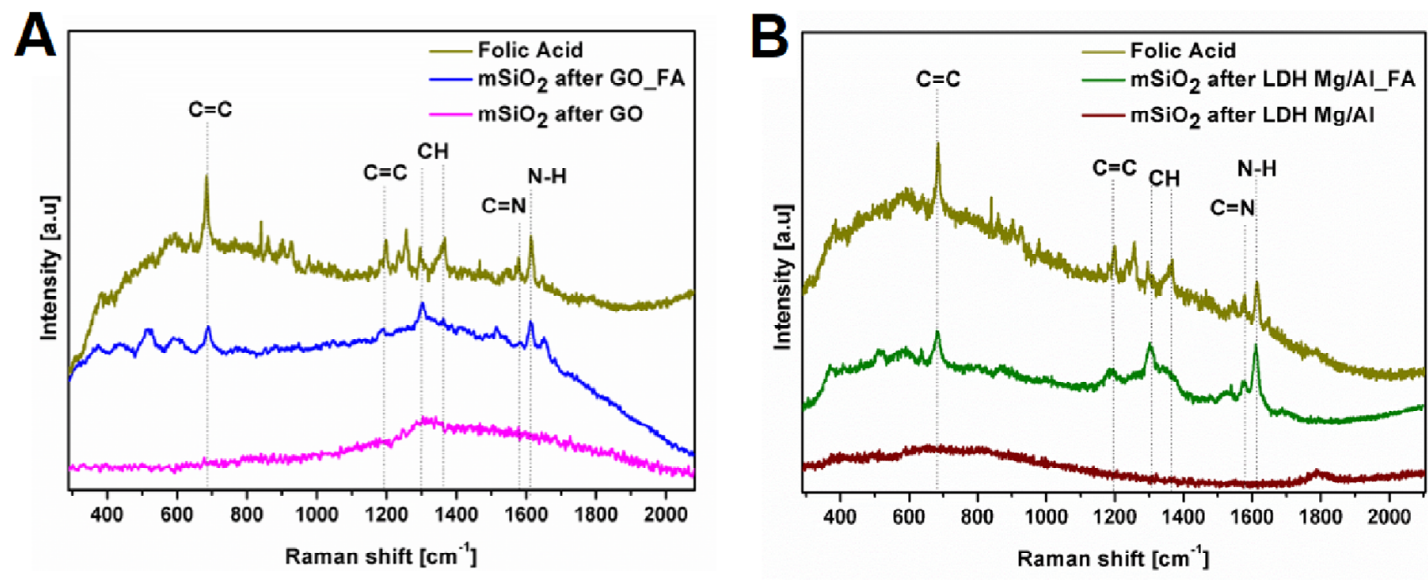

Figure 4. Raman spectra of silica flakes functionalized with folic acid: $\mathrm{mSiO}_{2}$ after $\mathrm{LDH} \mathrm{Mg} / \mathrm{Al} \_\mathrm{FA}$ (A) and $\mathrm{mSiO}_{2}$ after GO_FA (B).

Figure 5 shows the FTIR spectra of both types of silica flakes functionalized with folic acid and loaded with MTX. The band at $1398 \mathrm{~cm}^{-1}$ observed in both spectra indicates the existence of hydrogen bonds that could be formed between the drug and the silica flakes (Figure 5). It could also be related to the $\mathrm{C}-\mathrm{H}$ bond stretching vibrations $[38,39]$. The band centered at $1450 \mathrm{~cm}^{-1}$ in both samples corresponds to the symmetric stretching mode of the COO-group, indicating the successful interaction of MTX and silica flakes [40]. It is also noteworthy that after packing the drug, in both samples, the peak corresponded to the N-H bonds disappears. Therefore, it can be assumed that the drug interacts with silica flakes not only by hydrogen bonding, but it also attaches to amino groups, thus forming an amide bond, as confirmed by the peak at $1540 \mathrm{~cm}^{-1}$, corresponding to the C-N bond [41].
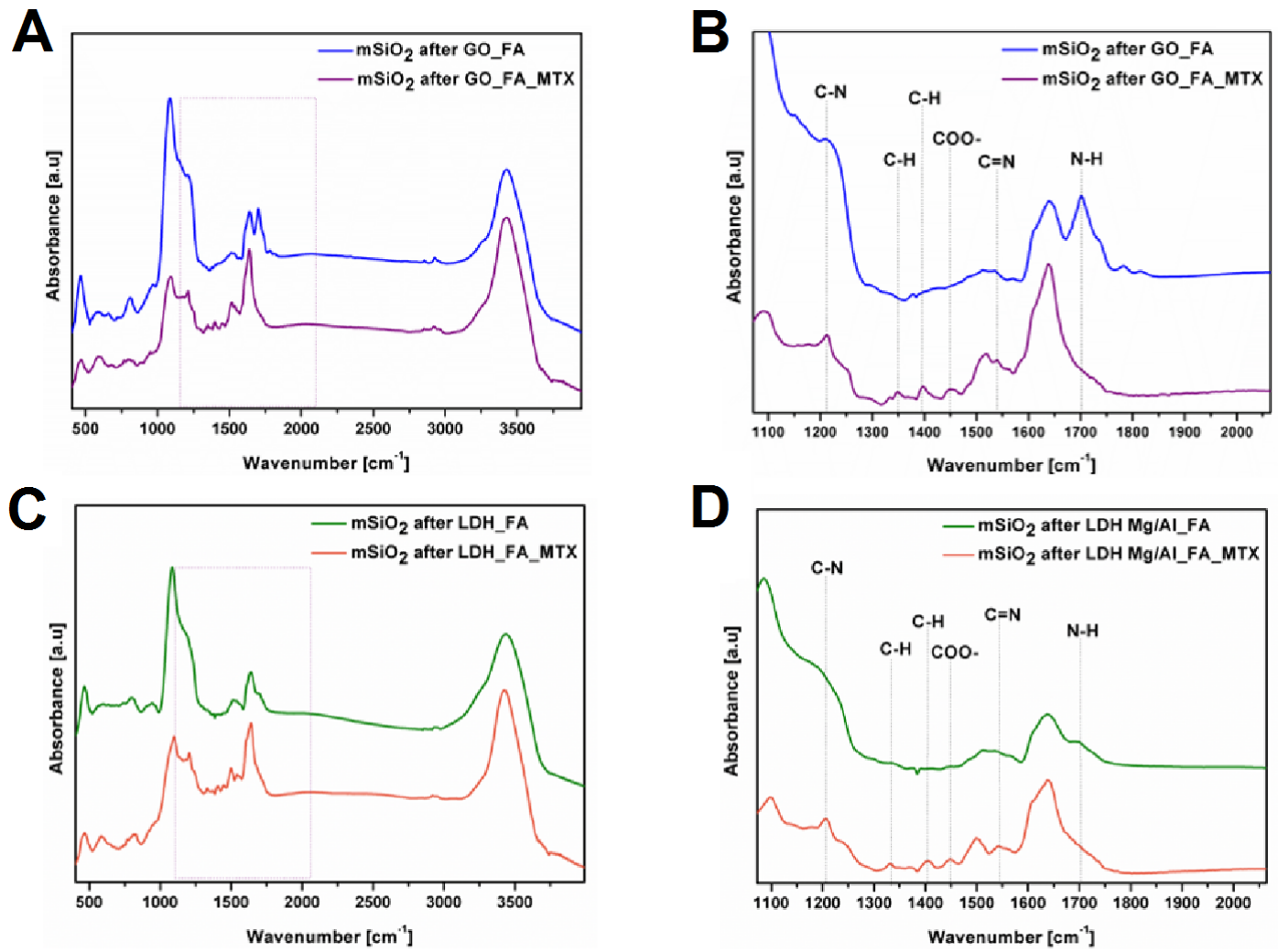

Figure 5. FTIR spectra of silica flakes functionalized with folic acid loaded with methotrexate (MTX): $\mathrm{mSiO}_{2}$ after GO_FA (A,B) and $\mathrm{mSiO}_{2}$ after LDH Mg/Al_FA (C,D). 
The thermogravimetric analysis (Figure S5) was carried out for silica flakes functionalized with folic acid and loaded with drug to determine the weight percentage of organic substances in the obtained structures. The obtained results allowed calculating that in the sample after functionalization with folic acid, $20 \mathrm{wt} \%$ of $\mathrm{mSiO}_{2}$ after $\mathrm{LDH} \mathrm{Mg} / \mathrm{Al}$ belongs to organic molecules and $23 \mathrm{wt} \%$ of $\mathrm{mSiO}_{2}$ after $\mathrm{GO}$ belongs to organic molecules. While for the samples after drug loading, the weight percentage of organic components was $50 \mathrm{wt} \%$ and $49 \mathrm{wt} \%$ for $\mathrm{mSiO}_{2}$ after $\mathrm{LDH} \mathrm{Mg} / \mathrm{Al}$ and $\mathrm{mSiO}_{2}$ after GO, respectively.

\subsection{Drug Release}

Drug release was carried out in deionized water (Figure 6A) and phosphate buffer saline solution (Figure $6 \mathrm{~B}$ ) at $37^{\circ} \mathrm{C}$. The equilibrium is achieved faster for $\mathrm{mSiO}_{2}$ after LDH. It was achieved in PBS after $2 \mathrm{~h}$ and in $\mathrm{H}_{2} \mathrm{O}$ after $4 \mathrm{~h}$, reaching $100 \mathrm{wt} \%$ and $80 \mathrm{wt} \%$, respectively. Whereas, in the case of $\mathrm{mSiO}_{2}$ after GO, small amounts of drug were still released even after $24 \mathrm{~h}$, eventually reaching $99 \mathrm{wt} \%$ in PBS and $\approx 93 \mathrm{wt} \%$ in water. At the early stages of the experiment, the immediate release of large amounts of drug was observed in both systems. It was not observed in earlier studies on non-functionalized mesoporous flakes [24]. It can be assumed that the presence of folic acid on the surface of the flakes blocks the drug penetration into the pores of the structures. Instead, it adsorbs on their surface and immediately releases after contact with solutions. In the case of $\mathrm{mSiO}_{2}$ after $\mathrm{GO}$, up to $80 \mathrm{wt} \%$ of the drug was adsorbed on the surface, while the rest of the amount of the drug filled the pores. However, in the case of $\mathrm{mSiO}_{2}$ after $\mathrm{LDH}$, even about $90 \mathrm{wt} \%$ of the drug could be adsorbed on the surface. These differences are due to the pore volume, which is three times larger in $\mathrm{mSiO}_{2}$ after $\mathrm{GO}$ than for $\mathrm{mSiO}_{2}$ after $\mathrm{LDH}$, so more drug could be adsorbed in the pores of the structure. This can also be confirmed via comparison of their release profiles in water. Since the solubility of methotrexate in water $(0.171 \mathrm{mg} / \mathrm{mL})$ [42] is much weaker than in PBS $(1 \mathrm{mg} / \mathrm{mL})$, the drug with $\mathrm{mSiO}_{2}$ after GO shows a gradual release, while with $\mathrm{mSiO}_{2}$ after $\mathrm{LDH}, \approx 60 \mathrm{wt} \%$ is released immediately. This confirms that in the case of $\mathrm{mSiO}_{2}$ after $\mathrm{GO}$, some of the drug must be desorbed from the pores, not just from the surface of the material. According to the presented FTIR (Figure 5), drug adsorbed on the surface of silica flakes are not only bound by the physical interactions, but it also attaches to amino groups, thus forming an amide bond. Except for the influence on drug releasing from silica flakes, the pore structure and drugs molecules bonding to their surface form the stability of silica flakes in the PBS solution. Our previous research shows that flake structures rapidly degrade. Therefore, this study was carried out to verify whether the different types of silica nanoflakes template affect this process as well.
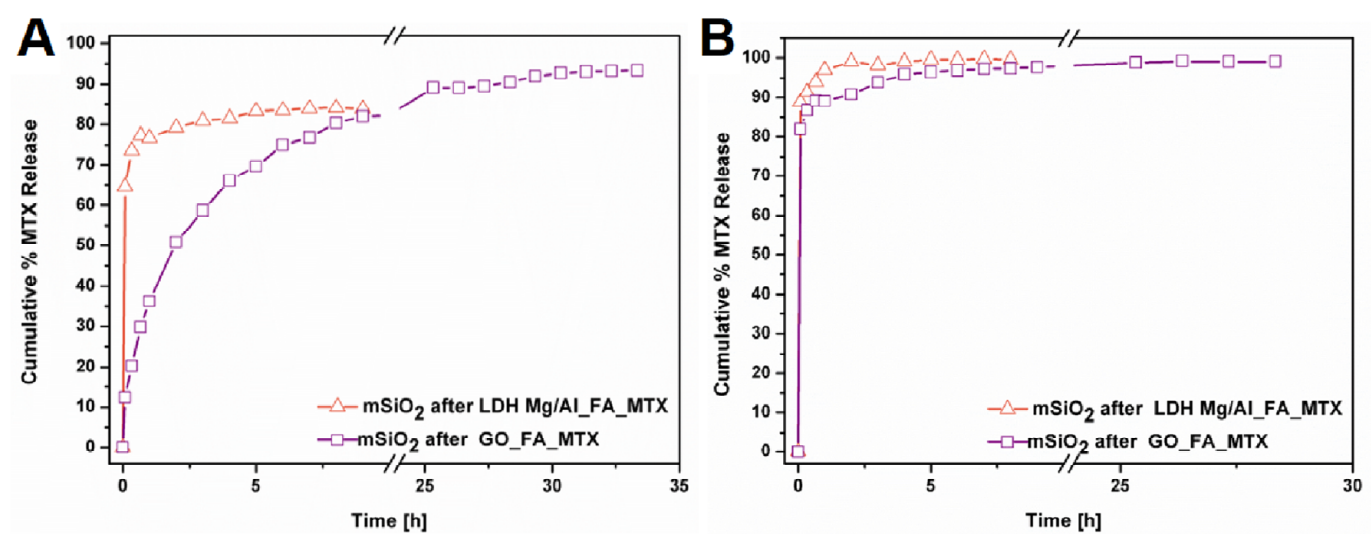

Figure 6. MTX releasing profiles in water (A) and phosphate-buffered saline (PBS) solution (B) at $37^{\circ} \mathrm{C}$.

\subsection{Degradation of Silica Flakes}

Recently, the degradation of silica structures has been widely investigated. Especially, this is crucial for biological applications because it is important that the material after its functionality (e.g., drug delivery) can be removed from its location without adversely affecting the cells. Silica materials 
are degraded due to hydrolysis of siloxane bonds (-Si-O-Si-). The current state of the art reports that factors such as size [43], shape [44], or porosity [45] may be important in the degradation rate of silica structures.

Basing on TEM images (Figures 7 and 8), it can be conclude that both kinds of silica flakes did not degrade in water, but PBS or medium had a huge influence on the materials' morphology. However, $\mathrm{mSiO}_{2}$ after GO placed in PBS (Figure 7D-F) first lose their porosity, without significant changes to the overall shape of the flake. After $48 \mathrm{~h}$ in medium (Figure $7 \mathrm{H}$ ), newly formed structures appeared, even though the porosity of the flakes is still visible. In the case of $\mathrm{mSiO}_{2}$ after $\mathrm{LDH} \mathrm{Mg} / \mathrm{Al}$, the overall shape of the flakes is maintained throughout the experiment, but the change in the porosity of the sample is also detected. The deformation appeared in the form of large holes in the nanoflakes structure.

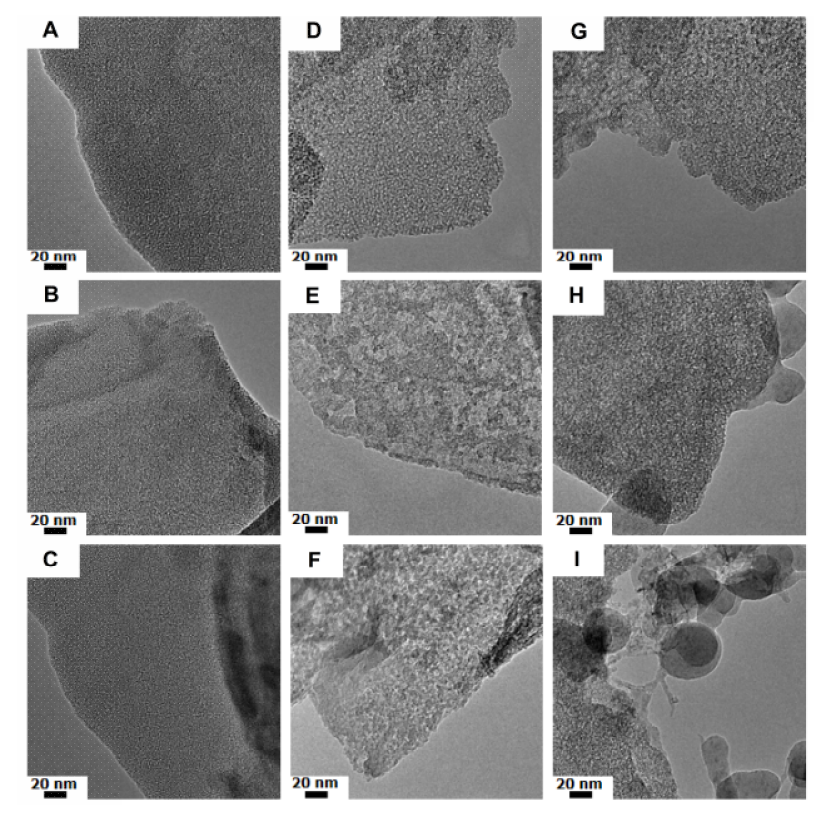

Figure 7. Transmission electron microscopy image of $\mathrm{mSiO}_{2}$ after $\mathrm{GO}$ immersed in water $(\mathbf{A}-\mathrm{C})$, the PBS solution (D-F) and medium (G-I) for $24 \mathrm{~h}$ (images A,D,G), $48 \mathrm{~h}(\mathbf{B}, \mathbf{E}, \mathbf{H})$, and $72 \mathrm{~h}(\mathbf{C}, \mathbf{F}, \mathbf{I})$.
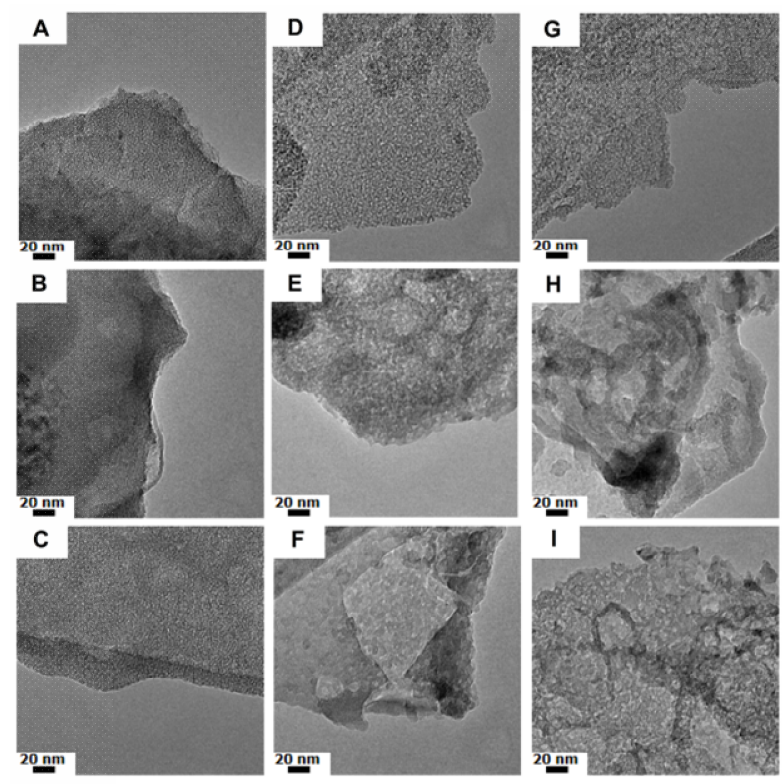

Figure 8. Transmission electron microscopy image of $\mathrm{mSiO}_{2}$ after $\mathrm{LDH}$ immersed in water (A-C), the PBS solution (D-F) and medium (G-I) for $24 \mathrm{~h}$ (images A,D,G), $48 \mathrm{~h}(\mathbf{B}, \mathbf{E}, \mathbf{H})$, and $72 \mathrm{~h}(\mathbf{C}, \mathbf{F}, \mathbf{I})$. 
Such differences in the process of flake degradation can be related to different effects. It can be e.g., due to the volume and size of the pores. Similar observations were described by B. Gouze and co-workers [46]. $\mathrm{mSiO}_{2}$ after $\mathrm{GO}$ has a smaller specific surface area, and at the same time their pore size is slightly smaller, but the volume is almost three times larger than in the case of $\mathrm{mSiO}_{2}$ after LDH. It is probable that the faster degradation of flakes after GO is caused by the solvent molecules, which are able to penetrate the structure faster and deeper. However, the fact that during the degradation of these flakes new and amorphous structures appear can be associated to the thickness of the flakes. The thin structure of the $\mathrm{mSiO}_{2}$ after $\mathrm{GO}$ exhibits a short diffusion path of the dissolved $\mathrm{SiO}_{2}$. The hydrolyzed silica during degradation did not settle on the flakes but was released into the solution. The newly formed silica particles such as spheres can be seen on Figure 7H,I. On the other hand, in the $\mathrm{mSiO}_{2}$ after LDH, the blocking pores and degradation of silica flakes after a shorter period of time can be detected. No additional silica structures were observed.

\section{Discussion}

The relationship between specific surface, pore type, and degradation rate was described by H. Yamanda et al. [43]. According to their research, not the size of the nanoparticles but rather the correlation with the specific surface and porosity of the structure is crucial in the degradation process of silica structures. Therefore, on one hand, it can be assumed that for $\mathrm{mSiO}_{2}$ after $\mathrm{GO}$, which is characterized by pores, a larger volume will be more suitable for drug delivery systems. However, the size of the nanoflakes and structures formed during degradation should also be taken into account. From previous reports on the interaction of nanoparticles with cells, it can be concluded that $600 \mathrm{~nm}$ particles are worse endocytosed by cells than spherical nanoparticles (size distribution from 80 to $150 \mathrm{~nm}$ ) [47]. This is also confirmed by other reports; e.g., Lin et al. show that well-ordered mesoporous silica nanoparticles with a size of $\approx 110 \mathrm{~nm}$ have been high-efficiently internalized into mouse fibroblast cells [48]. In addition, the shape can be important in these processes. It has been proven that longitudinal nanoparticles (longer dimension $\approx 110-150 \mathrm{~nm}$ ) penetrate cells better than longitudinal nanoparticles with smaller dimensions or spheres [49,50]. Therefore, it can be assumed that $\mathrm{mSiO}_{2}$ after $\mathrm{GO}$ can exhibit better potential use as drug delivery systems due to both a larger pore volume and smaller flake size. It can also be assumed that the newly formed structures during degradation will not penetrate the cells as easily as nanoflakes. However, the flakes should be subjected to further investigation.

\section{Conclusions}

We presented synthesis routes of silica flakes fabricated on two types of templates: on graphene oxide and $\mathrm{Mg}-\mathrm{Al}$ layered double hydroxide. Both types of silica flakes have been functionalized by folic acid and anticancer drug (MTX). Detailed spectroscopic analyses allowed proving that the drug interacts with silica flakes not only via hydrogen bonding, but also via amide bond formation. Interestingly, different structural properties affected their drug release profiles.

In all experiments there was at least $80 \mathrm{wt} \%$ drug release observed. The release, in water as well as in PBS solution, from $\mathrm{mSiO}_{2}$ after $\mathrm{GO}$ was slower and more gradual than from $\mathrm{mSiO}_{2}$ after $\mathrm{LDH}$. For the first structure, the release stopped after $30 \mathrm{~h}$, reaching $90 \mathrm{wt} \%$ in water and $\approx 99 \mathrm{wt} \%$ in PBS solution. Drug release from $\mathrm{mSiO}_{2}$ after $\mathrm{LDH} \mathrm{Mg} / \mathrm{Al}$ occurred almost immediately in both media (water and PBS). The equilibrium was achieved in PBS after $2 \mathrm{~h}$, while in $\mathrm{H} 2 \mathrm{O}$, it was achieved after $4 \mathrm{~h}$, reaching $100 \mathrm{wt} \%$ and $80 \mathrm{wt} \%$, respectively. This can be explained by the smaller pore volume of these structures allowing the drug adsorption only on the surface and not into the pores of the material

Both kind of flakes also degraded differently in the solutions. In water, none of the petals showed the changes in morphology. In contrast, the PBS solution and medium significantly affected the structure of the flakes. However, $\mathrm{mSiO}_{2}$ after GO placed in PBS and medium lost their porosity, and newly formed structures appeared. In the case of $\mathrm{mSiO}_{2}$ after $\mathrm{LDH} \mathrm{Mg} / \mathrm{Al}$, the overall shape of the flakes is maintained throughout the experiment, but a change in the porosity of the sample is also detected. The deformation appeared in the form of large holes in the nanoflakes structure. According 
to the TEM analysis, the degradation occurs faster for the flakes made from GO. These differences can be noticed after $48 \mathrm{~h}$.

Analyzing the data, it can be assumed that $\mathrm{mSiO}_{2}$ after $\mathrm{GO}$ can be more suitable as a drug delivery system due to the following: (i) the larger volume of pores in which the drug can be accumulated, and (ii) the smaller size of flakes that would more easily penetrate the cells. The obtained results are promising, but they require further research, primarily biological, to determine whether this folic acid functionalization combined with silica flakes will be effective in targeted anticancer therapies.

Supplementary Materials: The following are available online at http://www.mdpi.com/2076-3417/10/18/6465/s1, Figure S1: X-ray dispersion spectroscopy (EDX) elemental spectra of silica flakes and the templates; Figure S2: XRD patters of $\mathrm{mSiO}_{2}$ after $\mathrm{GO}(\mathrm{A})$ and $\mathrm{GO}$ and $\mathrm{mSiO}_{2}$ after $\mathrm{LDH} \mathrm{Mg} / \mathrm{Al}$ and $\mathrm{LDH} \mathrm{Mg} / \mathrm{Al}(\mathrm{B})$; Figure S3: Raman spectra of $\mathrm{mSiO}_{2}$ after $\mathrm{GO}(\mathrm{A})$ and $\mathrm{GO}$ and $\mathrm{mSiO}_{2}$ after $\mathrm{LDH} \mathrm{Mg} / \mathrm{Al}$ and $\mathrm{LDH} \mathrm{Mg} / \mathrm{Al}$ (B); Figure S4: BET isotherms (A) and diagrams of pore diameter distribution (B) of $\mathrm{mSiO}_{2}$ after $\mathrm{GO}$ and $\mathrm{mSiO}_{2}$ after $\mathrm{LDH} \mathrm{Mg} / \mathrm{Al}$; Figure S5: Thermogravimetric analysis of silica flakes functionalized with folic acid.

Author Contributions: Conceptualization, M.T. and K.C.; methodology, M.T.; investigation, M.T. and W.K.; writing—original draft preparation, M.T.; writing—review and editing, E.M. and K.C.; supervision, M.T. and E.M.; All authors have read and agreed to the published version of the manuscript.

Funding: This research was funded by National Science Centre, Poland, grant number 2016/21/N/ST8/02397.

Acknowledgments: The authors are grateful for the financial support of National Science Centre within PRELUDIUM 11 program (no. 2016/21/N/ST8/02397)

Conflicts of Interest: The authors declare no conflict of interest.

\section{References}

1. Fiori, G.; Bonaccorso, F.; Iannaccone, G.; Palacios, T.; Neumaier, D.; Seabaugh, A.; Banerjee, S.K.; Colombo, L. Electronics based on two-dimensional materials. Nat. Nanotechnol. 2014, 9, 768-779. [CrossRef] [PubMed]

2. Deng, D.; Novoselov, K.; Fu, Q.; Zheng, N.; Tian, Z.; Bao, X. Catalysis with two-dimensional materials and their heterostructures. Nat. Nanotechnol. 2016, 11, 218-230. [CrossRef] [PubMed]

3. Yang, S.; Feng, X.; Wang, L.; Tang, K.; Maier, J.; Müllen, K. Graphene-based nanosheets with a sandwich structure. Angew. Chem. Int. Ed. 2010, 49, 4795-4799. [CrossRef] [PubMed]

4. Wang, Z.M.; Wang, W.; Coombs, N.; Soheilnia, N.; Ozin, G.A. Graphene oxide-periodic mesoporous silica sandwich nanocomposites with vertically oriented channels. ACS Nano 2010, 4, 7437-7450. [CrossRef] [PubMed]

5. Guardia, L.; Suárez-García, F.; Paredes, J.I.; Solís-Fernández, P.; Rozada, R.; Fernández-Merino, M.J.; Martínez-Alonso, A.; Tascón, M.D. Synthesis and characterization of graphene-mesoporous silica nanoparticle hybrids. Microporous Mesoporous Mater. 2012, 160, 18-24. [CrossRef]

6. Liu, Y.; Li, W.; Shen, D.; Wang, C.; Li, X.; Pal, M.; Zhang, R.; Chen, L.; Yao, C.; Wei, Y.; et al. Synthesis of Mesoporous Silica/Reduced Graphene Oxide Sandwich-Like Sheets with Enlarged and "Funneling" Mesochannels. Chem. Mater. 2015, 27, 5577-5586. [CrossRef]

7. Harrison, R.; Li, L.; Gu, Z.; Xu, Z.P. Controlling mesoporous silica-coating of layered double hydroxide nanoparticles for drug control release. Micropor. Mesoporous Mater. 2017, 238, 97-106. [CrossRef]

8. Trewyn, B.G.; Slowing, I.I.; Giri, S.; Chen, H.T.; Lin, V.Y. Synthesis and functionalization of a mesoporous silica nanoparticle based on the sol-gel process and applications in controlled release. Acc. Chem. Res. 2007, 40, 846-853. [CrossRef]

9. Vialpando, M.; Aerts, A.; Persoons, J.; Martens, J.; Van Den Mooter, G. Evaluation of ordered mesoporous silica as a carrier for poorly soluble drugs: Influence of pressure on the structure and drug release. J. Pharm. Sci. 2011, 100, 3411-3420. [CrossRef]

10. Van Speybroeck, M.; Barillaro, V.; Thi, T.D.; Mellaerts, R.; Martens, J.; Van Humbeeck, J.; Vermant, J.; Annaert, P.; Van Den Mooter, G.; Augustijns, P. Ordered mesoporous silica material SBA-15: A broad-spectrum formulation platform for poorly soluble drugs. J. Pharm. Sci. 2009, 98, 2648-2658. [CrossRef]

11. Tarn, D.; Ashley, C.E.; Xue, M.; Carnes, E.C.; Zink, J.I.; Brinker, C.J. Mesoporous Silica Nanoparticle Nanocarriers: Biofunctionality and Biocompatibility. Acc. Chem. Res. 2013, 46, 3792-3801. [CrossRef] 
12. Takahashi, R.; Sato, S.; Sodesawa, T.; Kawakita, M.; Ogura, K. High Surface-Area Silica with Controlled Pore Size Prepared from Nanocomposite of Silica and Citric Acid. J. Phys. Chem. B 2000, 104, 12184-12191. [CrossRef]

13. Zhu, Y.; Shi, J.; Li, Y.; Chen, H.; Shen, W.; Dong, X. Storage and release of ibuprofen drug molecules in hollow mesoporous silica spheres with modified pore surface. Microporous Mesoporous Mater. 2005, 85, 75-81. [CrossRef]

14. Tang, F.; Li, L.; Chen, D. Mesoporous Silica Nanoparticles: Synthesis, Biocompatibility and Drug Delivery. Adv. Mater. 2012, 24, 1504-1534. [CrossRef]

15. Li, J.; Li, X.; Huang, Y.; Zhong, Y.; Lan, Q.; Wu, X.; Hu, R.; Zhang, G.; Hu, X.; Yang, Z. Biofunctionalized mesoporous silica nanospheres for the ultrasensitive chemiluminescence immunoassay of tumor markers. New J. Chem. 2018, 42, 11264-11267. [CrossRef]

16. Cha, B.G.; Kim, J. Functional mesoporous silica nanoparticles for bio-imaging applications. WIREs Nanomed. Nanobiotechnol. 2018, 11, 11-e1515. [CrossRef]

17. Martín-Saavedra, F.M.; Ruíz-Hernández, E.; Boré, A.; Arcos, D.; Vallet-Regí, M.; Vilaboa, N. Magnetic mesoporous silica spheres for hyperthermia therapy. Acta Biomater. 2010, 6, 4522-4531. [CrossRef]

18. Fang, W.; Tang, S.; Liu, P.; Fang, X.; Gong, J.; Zheng, N. Pd nanosheet-covered hollow mesoporous silica nanoparticles as a platform for the chemo-photothermal treatment of cancer cells. Small 2012, 8, 3816-3822. [CrossRef]

19. Tsai, C.P.; Chen, C.Y.; Hung, Y.; Chang, F.H.; Mou, C.Y. Monoclonal antibody-functionalized mesoporous silica nanoparticles (MSN) for selective targeting breast cancer cells. J. Mater. Chem. 2009, 19, 5737-5743. [CrossRef]

20. Tan, J.; Yang, N.; Hu, Z.; Su, J.; Zhong, J.; Yang, Y.; Yu, Y.; Zhu, J.; Xue, D.; Huang, Y.; et al. Aptamer-Functionalized Fluorescent Silica Nanoparticles for Highly Sensitive Detection of Leukemia Cells. Nanoscale Res. Lett. 2016, 11, 298-306. [CrossRef] [PubMed]

21. Rosenholm, J.M.; Meinander, A.; Peuhu, E.; Niemi, R.; Eriksson, J.E.; Sahlgren, C.; Lindén, M. Targeting of Porous Hybrid Silica Nanoparticles to Cancer Cells. ACS Nano 2009, 3, 197-206. [CrossRef]

22. Shan, W.; Wang, B.; Zhanga, Y.; Tang, Y. Fabrication of lotus-leaf-like nanoporous silica flakes with controlled thickness. Chem. Commun. 2005, 1877-1879.

23. Xiao, Z.; Zhao, Y.; Huang, Z.; Li, Y.; Li, B. Preparation of silica nanoflakes with spherical mesopores using a dual-templating approach. Mater. Lett. 2014, 135, 233-236. [CrossRef]

24. Mijowska, E.; Cendrowski, K.; Barylak, M.; Konicki, W. Sandwich-like mesoporous silica flakes for anticancer drug transport—Synthesis, characterization and kinetics release study. Colloids Surf. B 2015, 136, 119-125. [CrossRef] [PubMed]

25. Peruzynska, M.; Szelag, S.; Trzeciak, K.; Kurzawski, M.; Cendrowski, K.; Barylak, M.; Roginska, D.; Piotrowska, K.; Mijowska, E.; Drozdzik, M. In vitro and in vivo evaluation of sandwich-like mesoporous silica nanoflakes as promising anticancer drug delivery system. Int. J. Pharm. 2016, 506, 458-468. [CrossRef]

26. Low, P.S.; Kularatne, S.A. Folate-targeted therapeutic and imaging agents for cancer. Curr. Opin. Chem. Biol. 2009, 13, 256-262. [CrossRef] [PubMed]

27. Hagner, N.; Joerger, M. Cancer chemotherapy: Targeting folic acid synthesis. Cancer Manag. Res. 2010, 2, 293-301. [PubMed]

28. Rezaei, B.; Heidarbeigy, M.; Ensafi, A.A.; Dinari, M. Electrochemical Determination of Papaverine on $\mathrm{Mg}-\mathrm{Al}$ Layered Double Hydroxide/Graphene Oxide and CNT Modified Carbon Paste Electrode. IEEE Sens. J. 2016, 16, 3496-3503. [CrossRef]

29. Anovitz, L.M.; Cole, D.R. Characterization and Analysis of Porosity and Pore Structures. Rev. Mineral. Geochem. 2015, 80, 61-164. [CrossRef]

30. Kruk, M.; Jaroniec, M.; Sayari, A. Application of large pore mcm-41 molecular sieves to improve pore size analysis using nitrogen adsorption measurements. Langmuir 1997, 13, 6267-6273. [CrossRef]

31. Nandiyanto, A.B.D.; Kim, S.G.; Iskandar, F.; Okuyama, K. Synthesis of spherical mesoporous silica nanoparticles with nanometer-size controllable pores and outer diameter. Microporous Mesoporous Mater. 2009, 120, 447-453. [CrossRef]

32. Yao, Y.; Lu, H.; Li, J.; Peng, Q.; Wang, Q.; Li, Y.; He, X.; Leng, J. Electrospun silica-based inorganic/organic hybrid membranes with tunable performance in appropriate solvent systems. RSC Adv. 2015, 5, 89113-89120. [CrossRef] 
33. Stevanović, M.; Kovačević, B.; Petković, J.; Filipič, M.; Uskoković, D. Effect of poly- $\alpha, \gamma$, L-glutamic acid as a capping agent on morphology and oxidative stress-dependent toxicity of silver nanoparticles. Int. J. Nanomed. 2011, 6, 2837-2847. [CrossRef] [PubMed]

34. Sumayya, A.; Panicker, C.Y.; Varghese, H.T.; Harikumar, B. Vibrational Spectroscopic Studies and Ab Initio Calculations of L-Glutamic Acid 5-Amide. Rasayan J. Chem. 2008, 1, 548-555.

35. Castillo, J.J.; Rindzevicius, T.; Rozo, C.E.; Boisen, A. Adsorption and Vibrational Study of Folic Acid on Gold Nanopillar Structures Using Surface-enhanced Raman Scattering Spectroscopy. Nanomater. Nanotechnol. 2015, 5, 29-37. [CrossRef]

36. Castillo, J.J.; Rindzevicius, T.; Wu, K.; Rozo, C.E.; Schmidt, M.S.; Boisen, A. Silver-capped silicon nanopillar platforms for adsorption studies of folic acid using surface enhanced Raman spectroscopy and density functional theory. J. Raman Spectrosc. 2015, 46, 1087-1094. [CrossRef]

37. Kokaislová, A.; Helešicová, T.; Ončák, M.; Matějka, P. Spectroscopic studies of folic acid adsorbed on various metal substrates: Does the type of substrate play an essential role in temperature dependence of spectral features? J. Raman Spectrosc. 2014, 45, 750-757. [CrossRef]

38. Wang, W.Y.; Zhao, X.F.; Ju, X.H.; Wang, Y.; Wang, L.; Li, S.P.; Li, X.D. Novel morphology change of Au-Methotrexate conjugates: From nanochains to discrete nanoparticles. Int. J. Pharm. 2016, 515, 221-232. [CrossRef]

39. Xu, Y.; Li, D.; Liu, M.; Niu, F.; Liu, J.; Wang, E. Enhanced-quantum yield sulfur/nitrogen co-doped fluorescent carbon nanodots produced from biomass Enteromorpha prolifera: Synthesis, posttreatment, applications and mechanism study. Sci. Rep. 2017, 7, 4499. [CrossRef]

40. Huo, X.; Dai, C.; Li, S.; Li, X. Synthesis of Au yolk/LDH shell nanoparticles as anticancer vehicles. RSC Adv. 2015, 5, 8689-8692. [CrossRef]

41. Wang, C.F.; Mäkilä, E.M.; Kaasalainen, M.H.; Hagström, M.V.; Salonen, J.J.; Hirvonen, J.T.; Santos, H.A. Dual-drug delivery by porous silicon nanoparticles for improved cellular uptake, sustained release, and combination therapy. Acta Biomater. 2015, 16, 206-214. [CrossRef] [PubMed]

42. DRUGBANK. Available online: https://www.drugbank.ca/drugs/DB00563 (accessed on 13 May 2020).

43. Yamada, H.; Urata, C.; Aoyama, Y.; Osada, S.; Yamauchi, Y.; Kuroda, K. Preparation of colloidal mesoporous silica nanoparticles with different diameters and their unique degradation behavior in static aqueous systems. Chem. Mater. 2012, 24, 1462-1471. [CrossRef]

44. Hao, N.; Liu, H.; Li, L.; Chen, D.; Li, L.; Tang, F. In vitro degradation behavior of silica nanoparticles under physiological conditions. J. Nanosci. Nanotechnol. 2012, 12, 6346-6354. [CrossRef] [PubMed]

45. Choi, E.; Kim, S. How can doxorubicin loading orchestrate in vitro degradation behaviors of mesoporous silica nanoparticles under a physiological condition? Langmuir 2017, 33, 4974-4980. [CrossRef]

46. Gouze, B.; Cambedouzou, J.; Parrès-Maynadié, S.; Rébiscoula, D. How hexagonal mesoporous silica evolves in water on short and long term: Role of pore size and silica wall porosity. Microporous Mesoporous Mater. 2014, 183, 168-176169. [CrossRef]

47. Trewyn, B.G.; Nieweg, J.A.; Zhao, Y.; Lin, V.S.Y. Biocompatible mesoporous silica nanoparticles with different morphologies for animal cell membrane penetration. Chem. Eng. J. 2008, 137, 23-29. [CrossRef]

48. Lin, Y.S.; Tsai, C.P.; Huang, H.Y.; Kuo, C.T.; Hung, Y.; Huang, D.M.; Chen, Y.C.; Mou, C.Y. Well-ordered mesoporous silica nanoparticles as cell markers. Chem. Mater. 2005, 17, 4570-4573. [CrossRef]

49. Huang, X.; Teng, X.; Chen, D.; Tang, F.; He, J. The effect of the shape of mesoporous silica nanoparticles on cellular uptake and cell function. Biomaterials 2010, 31, 438-448. [CrossRef] [PubMed]

50. Hao, N.; Linlin, L.; Zhang, Q.; Huang, X.; Meng, X.; Zhang, Y.; Chen, D. The shape effect of PEGylated mesoporous silica nanoparticles on cellular uptake pathway in Hela cells. Microporous Mesoporous Mater. 2012, 162, 14-23. [CrossRef]

(C) 2020 by the authors. Licensee MDPI, Basel, Switzerland. This article is an open access article distributed under the terms and conditions of the Creative Commons Attribution (CC BY) license (http://creativecommons.org/licenses/by/4.0/). 